This is an Author Accepted Manuscript (AAM), a post-peer-review, pre-copyedit version of an article Villacañas de Castro, Luis S. (2020). Deweyan democracy, neoliberalism, and action research. Studies in Philosophy and Education, 39(1), 19-36. DOI: 10.1007/s11217019-09664-1. The final authenticated version is available online at https://link.springer.com/article/10.1007\%2Fs11217-019-09664-1

\title{
Deweyan democracy, neoliberalism, and action research
}

\begin{abstract}
This article aims to establish a line of continuity between John Dewey's democratic and educational ideals and the practice of action research, to justify that the latter affords an adequate means to enact Dewey's ideals against the destructive challenges that neoliberalism poses to democracy today. This aim involves three ideas that will be developed in three corresponding sections. After the Introduction, the first section analyzes at length the main tenets of Dewey's thoughts about democracy by emphasizing the role of the educational dimension. The article then approaches neoliberalism by focusing on one of its variants, New Public Management, and explains why the latter implies a direct erasure of Dewey's ideals concerning democracy, individual growth, education, and social advancement. Finally, the third section turns to action research and its potential to encourage our societies to move closer to Dewey's democratic ideals, and suggests that action research can begin to fill the gap that Dewey's work left concerning the institutional dimension of democracy.
\end{abstract}

Keywords. John Dewey, Democracy, Education, Neoliberalism, Action research, Institutions and Administration 


\section{Introduction}

This article aims to establish a line of continuity between Dewey's democratic and educational ideals and the practice of action research, and then to justify why the latter is an adequate means to actualize Dewey's ideals in today's society, and implement them against the destructive challenges that neoliberalism poses to democracy. Though the article establishes no new connection (Dewey remains an essential figure for educational thought and in action research literature) not many texts have brought together his political and educational philosophies and how they relate to neoliberalism and action research into a single, coherent argument, as this text wishes to do. As such, the article finds inspiration in the belief that Dewey's understanding of democracy continues to be valid and transformative today, in an age defined by neoliberalism; and, additionally, that action research has inherited this potential for transformation.

The backbone of this article is a reading of Dewey that is partial in a quantitative and qualitative sense of the word. Firstly, the interpretation offered in the following section is mainly reduced to his magnum opus, Democracy and education, together with minor early and middle works. Secondly, the explanation and analysis of Dewey's philosophy draws on conceptual and logical tropes that are not easily found in his own pages, and which may even be considered foreign to American pragmatist philosophy as a whole - these tropes being "opposition", "synthesis", “determination", and "structure”, which betray my own foundation in European critical theory. Although far, I hope, from having concocted a fictional Dewey of the sorts Richard Rorty made up in a lovely paper from 1988, wherein he basically made Dewey write what he would have liked him to say, this article acknowledges from the outset the idiosyncratic character of its reading of the American pragmatist in establishing a specific connection between his philosophy, action research, 
and neoliberalism. At the heart of this conceptual enterprise remains, however, what I believe to be the main idea also in Dewey's thought and, especially, in Democracy and education: namely, that democracy is the way through which education and society could improve themselves. As Stone (2016) has noted, “when considering Dewey's definition [of democracy] it is significant that it is fundamentally a view of education" (p. 79). This basic idea is our point of departure.

\section{Democracy, schools, and society}

Dewey was never more concrete about that "form of associated living . . . [of] conjoint communicated experience" (Dewey 1916/2012, p. 101) which he called democracy than when he identified it with a "number of individuals ... participat[ing] in an interest so that each has to refer his own action to that of others, and to consider the action of others to give point and direction to his own" (p. 101). For him democracy was a complex form of socialization involving individuals who identified their common interests and coordinated their thoughts and actions to materialize their shared goals. Democracy, in other words, existed whenever individuals freely and equally participated in the theoretical and material production of the world and of their society, in designing its aims but also in bringing them into practice. Of course, the concrete, historical realizations of this abstract definition varied greatly from one political system and historical period to another; some societies actualized the democratic idea to a fuller and wider extent than others. Nevertheless, Dewey (1927/1998) insisted that democracy was consubstantial with human socialization or, in his own words, that "democracy is not an alternative to the principles of associated life. It is the idea of community life itself' (p. 295). As the first chapters of Democracy and education (and other works) make clear, no human community could 
survive without including a minimum of democratic life within itself. In this sense, Straume (2016) argued that Dewey’s conception of democracy would be "prepolitical” (p. 40).

It should now be easier to picture the two-fold, logical argument that Dewey plots in his major work. The reader can find this in Figure 1, articulated around two overlapping and inverted triangles. The book's architecture ties together two conceptual arguments, the first through which (1) this pre-political notion of democracy, understood as synonymous with the principles of interaction and associated life, unrolls itself and aspires to attain its perfect historical form, and secondly (2) a Hegelian-like dialectics in which the institutional opposition between school and society plays itself out and is theoretically resolved. The first argument involves only the abstract concept of democracy as it is "carried to its final limit, viewed as completed, perfected" (p. 295), while the second one plots a complex dialectics between two historically differentiated institutional realities. Were we to visually represent Dewey's masterpiece, as does Figure 1, then the first conceptual linedemocracy's travail toward its ideal realization in history: the growing possibilities for interaction and living that democracy would be able to encompass, symbolized by the gradual widening of the triangle's base - would act at the same time as a vertical axis around which the institutional dialectics between school and society would simultaneously develop itself. The partial realizations of democracy would correspond to the yet imperfect ways in which society and the schools interrelated at certain periods in history. At the end, in their final synthesis, the concepts of school and society would joyfully collapse into the other: having accomplished their best democratic possibilities, education would become undistinguishable from social life, and social life from education. Yet rather than narrowing or bringing history to a close, the ideal synthesis of school with the rest of institutions of society would coincide with the full expansion of human interaction, the embodiment of the 
democratic ideal in perfected institutions, the stage in which human beings would finally be able to interact among themselves and with nature free at last, not of institutions tout court, but of the tensions deriving from their internal dialectics.

Figure 1 identifies five critical moments in the dialectical unfolding of schools and the rest of institutions of society. Some of these moments actually took place in history while others did not and, accordingly, belong to a future that is more or less utopian, as has been said (Bernstein 2010; Cunha 2016). I am concerned here only with logical moves or qualitative breakthroughs rather than with their historical realization. "It goes without saying”, Dewey (1916/2012) admitted, "that we are far from such a social state; in a literal and quantitative sense, we may never arrive at it" (p. 370). Still, the inaugural moment of the school/society dialectics does connect to a historical event; I am referring to the founding, at some point during the middle Ages, of the school as a specific, educational institution. Only then did it make sense to speak of a contradiction and an ensuing dialectics, when schools emerged as something different from the rest of the social milieu, and educating became a specific social practice. According to Chapter two of Democracy and education, schools originated out of the need to guarantee cultural heredity in societies that were growing more and more stratified and complex, on account of the social division of labor. In those social milieus, the young could no longer learn what they needed to become productive members of society in the same ways as the previous generations had done, i.e., through the direct interactions that children have at home with their parents, or the exchanges between master and apprentice.

Having explained the origin of schools in this way, Dewey then sets out to analyze their negative educational side effects. Before schools existed, he claims, education was rooted in the ebbs and flows of community life, indistinguishable from social interaction, 
embedded in numerous exchanges. Insofar as this was the case, education also participated in the democratic quality that — as said above—Dewey included to some extent in most forms of socialization. Education, understood as the experience through which individuals knew themselves and their environment better-and, as a result, grew better at transforming their reality according to better-defined aims (Dewey 1912/2012, p. 376) —was something that occurred while individuals identified their common interests and coordinated their thoughts and actions to materialize their shared goals. Yet once schools emerged as "mere teaching institutions", not "educating institutions"-a neat distinction proposed by Kerschensteiner (1933, p. 230, cited in Gonon 2000, p. 142) — this democratic quality could no longer permeate the interactions that occurred inside them.

This is the entrenched problem of schools qua schools. While socialized, contextualized, purposeful, and more or less democratic forms of learning continued to exist outside schools, inside them, by contrast, loads of theoretical content was transmitted at all costs in order to substitute for the collective uses of intelligence and practice, and at the expense of the relevance, purpose, and democratic qualities of the educative process. In doing so, Dewey pointed out that schools adopted a notion of knowledge that pertained to the advantaged social classes, which were the same ones whose younger generations the schools were primarily aimed at educating. Not by chance did the emergence of schools imply, according to Bauman (1987/2013), that a whole range of "traditional, self-managing and self-reproducing culture was laid in ruins" (p. 67). "Thus we reach the ordinary notion of education", said Dewey (1916/2012), "which ignores its social necessity and its identity with all human association that affects conscious life, and which identifies it with imparting information about remote matters and the conveying of learning through verbal signs" ( $p$. $10)$. 
Through the nearly five hundred pages of Democracy and education, Dewey labored hard to find a solution to this problem, which plagued education in his day as much as it does ours. His solution consisted of two dialectical moves: namely, (1) to socialize schools (2) so that schools would further democratize society. Each of these moves connected with one of the two conceptual lines exposed above. For instance, concerning the school/society institutional dialectics, Dewey claimed that the former should open up and decidedly import features from the most democratic institutions of US society: "The school”, in Noddings' (2010) words, "should be organized as a miniature society, one that incorporates the best features of the developing, democratic, larger society" (p. 283). Once this occurred, Dewey expected that the newly educated generations would leave school and transform the worst - i.e., least democratic — institutions and spaces in society, contributing in this way to democracy's historical refinement. Let us deal separately with each of these dialectical moves.

\section{To socialize schools...}

Dewey (1916/2012) described the first move in the 1915 Preface to Democracy and education: "The following pages embody an endeavor to detect and state the ideas implied in a democratic society and to apply these ideas to the problems of the enterprise of education" (p. v). To become fully socialized, schools had to assume features coming mainly from three institutions: the household, the political institutions of the US republic, and industrial production. All three carried with them democratic features that schools would have to synthesize and transform into a new kind of educational reality. From families, Dewey (1915/2001, p. 24) thought that schools could reproduce the manner in which informal learning occurred at home, in ways that were fully contextualized in terms of familial purposes and material resources. From the US political system, on the other 
hand, schools could apply the kind of institutional inventiveness (Stone 2016) through which political institutions had extended deliberation and decision-making among the different segments of the population, disregarding divisions of social class, gender, or race (Dewey 1916/2012, p. 304).

Yet the main inspiration for schools should come from economic production and especially from industrial work. In actuality, the latter realized democracy to a fuller extent than universities or academia in general, peopled by learned intellectuals laboring at the other side of the theory and practice divide (Dewey 1916/2012, p. 272). In terms of the democratic — and educational—quality of its interactive processes, for Dewey the only thing missing from industrial work under capitalism was for the workers to freely decide the aims and interests of their own labor and production processes, and also for them to deliberate on and design how to better fulfill those common aims. As for the remainder of democratic standards, industrial work satisfied them all: it was a purposeful activity involving constant interaction with the natural and social worlds, and informed - as will be explained next — by inquiry and scientific knowledge. It was therefore full of the potential to "intensify and enlarge the scope of conscious experience" (p. 350), which was characteristic of educational and democratic experiences alike.

To turn industrialized production into an ideal unit of social life, however, it was first necessary to blow democratic intelligence into it, which in turn involved two things: First, to disclose and bring home to workers the immense scientific knowledge that lay behind the technological breakthroughs that had already revolutionized all economic sectors. After two industrial revolutions, Dewey (1916/2012) considered that "industry has ceased to be essentially an empirical, rule-of-thumb procedure, hand down by custom. Its technique is now technological: that is to say, based upon machinery resulting from discoveries in 
mathematics, physics, chemistry, bacteriology, etc.” (p. 367). Now that economic production was applied science, there was no reason why workers should not educate or familiarize themselves with the immense scientific knowledge that subtended their work, further narrowing the gap between theory and practice. Furthermore, it was also necessary for industrial workers to provide themselves with an institutional architecture that enabled them to collectively identify common goals and design and supervise the steps necessary to realize them. In other words, industrial production had to import from politics its democratic institutional reach (p. 304). On this regard, Bernstein (2010), Gonon (2000), and Straume (2016) criticized Dewey for his "little emphasis on institutional analysis—on what sorts of institutions are required for a flourishing democracy" (Bernstein 2010, pp. 304-5). More on this in the final section.

Ultimately, the desired educational synthesis of family life, of the political institutions in the republic, and industrial production came in the form of occupations, "a mode of activity on the part of the child which reproduces, or runs parallel to, some form of work carried on in social life" (Dewey 1915/2001, p. 83). Occupations were fully described in chapter XXIII of Democracy and education: "The key to the present educational situation", it said, "lies in a gradual reconstruction of school materials and methods so as to utilize various forms of occupations typifying social callings, and to bring out their intellectual and moral content" (1916/2012, p. 369). Considered as pedagogical units, occupations were different from anything schools had imagined until then: Inspired by the economic sphere, Dewey's hope was that through occupations schools would harmoniously integrate practical and intellectual work into a single pedagogical action (Kliebard 2006). School socialization through occupations would channel the experimental quality found in workshops, industrial production, and scientific laboratories towards the fulfillment of 
social aims that, in this case, the whole school community-children, teachers, even parents - would have previously deliberated on, agreed upon, and designed. On the other hand, occupations were equally distant from the economical, profit-oriented emphasis of vocational education (Boostrom 2016) and from the elitist and fleshless theoretical production that characterized academia. "With school occupations," Dewey (1915/2001) explained,

the aim is not the economic value of the products, but the development of social power and insight. It is this liberation from narrow utilities, this openness to the possibilities of the human spirit, that makes these practical activities in the school allies of art and centers of science and history. (p. 13)

Occupations were the pedagogical units that Fritzpatrick (1918) would end up calling projects, which revolved around "hearty purposeful act[s]" (p. 4). In accordance with Dewey's argument, Fritzpatrick saw the latter as "the typical unit of the worthy life" so he logically concluded that they should also become "the typical unit of school procedure" (p. 6). Rather than a mere reproduction of an existing dynamics, school socialization through occupations should imply, above all else, an original and unexplored synthesis, a case for novelty. In terms similar to those employed by Luke (2018, p. xi), Dewey insisted on the idea that the same autonomy that had allowed schools to remain isolated for ages from the democratic quality that infused life into the rest of social spheres and institutions could also, under adequate circumstances, allow schools to simultaneously inaugurate unprecedented forms of communicative and productive social interaction. Schools should be able to move from the last wagon to the vanguard of democracy. Although their occupations retained the material and empirical qualities of economic production, they had no need to respect the capitalistic division of labor nor the need for profit that capitalism 
enforced. They could shape themselves in line with the democratic belief that people had the right to lead an inquiry, a design, an action plan, and finally transform their environment in line with a common good they had previously and freely discussed and agreed upon. So long as school occupations remained within these parameters, they would be truly educative in the sense of "add[ing] to the meaning of experience and which increases ability to direct the course of subsequent experience" (Dewey 1916/2012, p. 90).

\section{... to further democratize society}

In "My pedagogic creed", Dewey (1897/1998) stated that "education is the fundamental method of social progress and reform" (p. 234). In the context of Democracy and education's internal logic, this meant that once schools were able to reproduce within their walls the best examples of productive and democratic life, students so educated would step outside, into the social world, determined and resolved to amplify and deepen the quality of democracy whenever and wherever it was weaker and more precarious. Dewey trusted that these new generations of students, educated through occupations, would not settle for anything less than fully actualizing in their daily lives the whole range of practical and intellectual capacities they would have grown accustomed to inside these reformed schools. "Such an education will of itself tend to do away with the evils of the existing economic situation", Dewey (1916/2012, p. 304) assured. Socialized schools would form fully democratic citizens resolute and steadfast to fighting for a rich and worthwhile adult life.

This was Dewey's optimistic move, one through which new schools necessarily prefigured a new democratic society. Yet, as will be described in the next section, the outside world had its own entrenched economic problems that demanded specific, noneducational responses. Though generations educated in occupations might be more 
qualified to solve capitalism's problems, education by itself would not lead directly to the perfect democracy. Due to his resistance to analyze the institutional and economic changes necessary to implement his vision of democracy_above all, to guarantee that the control of the economic region did not "remain external and autocratic from the people" (1916/2012, p. 304)—Dewey did not describe this new society. He offered glimpses, though, of the new balances that should characterize it, but only as a contrast to the negative tendencies that he found in his own day. Overall, Dewey's idea of a more democratic society meant that divisions arising from social class, trade, race, or even gender, would never prevent all of its members from engaging in interactions in pursuit of new forms of communication and production (Detlefsen 1998). Social diversity should never result in social divides that democratic exchanges could not overcome; "the threats of differentiation and pluralitydistrust and conflict-[ should be] tempered by communication and common experiences" (Straume 2016, p. 33).

Figure 1 offers a concrete understanding of the logical contours of what life in Dewey's perfected democratic society might look like. Through its last phases, Figure 1 takes a qualitative step beyond the two dialectical moves explained above and ventures to suggest that, just as schools should import within their walls the purposeful logics of society, Dewey's (1916/2012) dialectics would then export project-work-redefined occupations — outside educational institutions, to the remaining institutions and social practices. In other words, dissolving the opposition between schools and society would demand that the entire community—not just school members — participated in educational projects, and in non-capitalistic versions of occupations which had already freed themselves "from extraneous associations and from the pressure of wage-earning . . . truly liberalizing in quality” (p. 235). As far as Democracy and education's logic suggests, Dewey's utopian 
society would be one in which school projects' democratic, social, and educational dynamics would end up permeating throughout the entire social realm. Projects would become the basic social unit regulating life in and outside of school. Ideal life would consist of a never-ending series of educational projects.

Thanks to this dialectical synthesis whereby the different social spheres and institutions ended up sharing the best of themselves with each other, Dewey's dialectics got rid of a series of oppositions and established different lines of continuity: not only between education and work, which would become undistinguishable in truly democratic society, but also between childhood and adult life. "Youth democracy," Stone (2008) argued, “fosters adult democracy” (p. 10). In line with Dewey’s (1897/1988) claim that education was "a process of living and not a preparation for future living" (p. 230), when designing and implementing concrete solutions to their most urgent problems, adult workers would actualize the same methodological unit that Dewey recommended schools use in order to activate children's talents in school environments: projects. Life had to be "growth" always, “continual reorganizing, reconstructing, transforming" (1916/2012, p. 59). And it had to be so at all costs, for the child as much as for the adult. The difference between the latter should not be one which distinguished "grown and not growth," Dewey insisted, "but between the modes of growth appropriate to different conditions" (p. 59).

[Figure 1. Dewey's (1916/2016) two-fold argument]

\section{Neoliberalism, privatization, and New Public Management}

In the end, occupations did not end up becoming the privileged pedagogical unit for educating in socialized, reformed schools; nor were they accordingly freed from capitalist pressure for profit; nor were they finally exported to the rest of spheres and institutions in society, as the structural unit for social interaction in democratic, communal life. None of 
this happened, which is why I claim in Figure 1 that these dialectical moments belong to a utopian future. Dewey had seen the seeds of radical democracy in North-American homes, politics, and industrial production, but the future would dictate otherwise. "The revolution is still incomplete", he wrote (1916/2012, p. 301) in 1916, and it would remain so.

According to Cunha (2016), a century after his masterpiece, "the contemporary world is being increasingly dominated by a mentality that diametrically diverges from what Dewey projected as possible ...; the relations we establish with each other are an instance of what Dewey called 'obstruction to full and flexible social interaction and intercourse"' (p. 31). As we now know, the future that actually happened was called neoliberalism. As shown in the impressive volume edited by Mirowki and Phehwe in 2009, The road from Mont Pèlerin. The making of the neoliberal thought collective, within the neoliberal cosmos there is a plurality of political practices and philosophical theories (some of which were being drafted in central Europe during Dewey's lifetime), all of which defy simplification of the term. To Dewey's credit, however, we can at least agree that neoliberalism was the culmination of some of the dynamics he denounced in his own day, related to the burgeoning separation between the corporate class and social majorities. Radical social division — democracy's main enemy_finally presented itself as a result of unfair wealth distribution and capital accumulation. On the backs of the immense surpluses generated by industrial capitalism, economic power and its political ramifications gradually allowed the corporate class to shape and control the non-economic institutions of society (education included) so that their internal workings would never lead to radical democratic transformations (Judt 2011). Rather than the final democratization of industrial production and thereby of the entire society, the twentieth century witnessed the nightmarish reversal 
of Dewey's promise: the ratio of capitalist profit colonized all of the spheres of social practice.

Many were the times (Dewey, 1916/1980, p. 138, for example) when Dewey included worrying remarks about power imbalance and the traces this was leaving on the ideological landscape of the United States. For instance, he identified a new individualism (Dewey 1931) or pseudo-liberalism which, by assimilating "democracy with economic individualism as the essence of free action, has done harm to the reality of democracy" (1941/1988, p. 277, cited in Detlefsen 1988, p. 312). In due time, neoliberalism would rise as the final distortion of liberalism, ready to redesign human sociability around anthropological concepts (Dardot \& Laval, 2010/2014) that were entirely foreign to Dewey's own tenets. In a similar fashion to how "the new individualism was interpreted philosophically ... as an assertion that each individual's mind was complete in isolation from anything else” (Dewey 1916/2012, p. 356), neoliberalism ended up translating individual agency - also towards oneself, as conveyed by human capital-exclusively in terms of economic entrepreneurship. Accordingly, instead of a diverse range of interactions occurring in a diverse range of social practices (including the home or political, economic, and educational institutions, each with its specific democratic potential) contemporary neoliberalism offers only one way for individuals to socialize and abandon their isolated nature: the market and its logic of supply and demand. Suddenly, investment and consumption become the only meaningful acts. No other dimensions of human nature and experience are considered, except as a qualification of the above. In the sphere of education, Knight Abowitz (2005) has also diagnosed and denounced the ill-gotten consequences of the "colonization of the public spheres by the private and particularly the market-based spheres of commerce" (p. 359. For education and neoliberalism, see also 
Boyles 2000 and Saltman 2015). Therefore, Harvey (2005) characterized neoliberalism as "a theory of political economic practices that proposes that human wellbeing can best be advanced by liberating individual entrepreneurial freedoms and skills within an institutional framework characterized by strong private property rights, free markets and free trade" (p. 2).

As for the paths through which neoliberalism imposed itself historically, there can be no doubt that privatization — "a transfer in control and/or ownership of business and industry from the public realm to the private" (Mansfield 2007, p. 393) - soon became the privileged strategy (Morales, Gendron, \& Guénin-Paracini 2014). Conceptually speaking, privatization based and still bases its success on the realization that, without the shelter of the State, nothing can protect the specific meanings, values, and forms of interaction through which the different social practices try to realize their particular aims through the State. It may sound paradoxical, but it was precisely by respecting the autonomy of health care, education, and social welfare, for example - the key pillars of the public sector - that the State participated in these social practices at the same time as it secured their specific ratios. This was the approach followed by the administrative model that prevailed in the post-war years of the twentieth century—Progressive (or traditional) Public Administration (PPA from now on)-, through which the western world strengthened both democracy and the welfare state (Box, Marshall, Reed, \& Reed 2001; Lynn Jr 2006 ; Vivian \& Maroun 2018). By respecting their autonomy and catering to the necessary conditions under which professionals working in each of these spheres could do their job well, PPA made sure that health care remained health care, and education, education. Conversely, these social practices counted on the protection of the State precisely because every citizen had the right to benefit from them. 
Through privatization, however, neoliberalism fueled the idea that the different social spheres - its respective practices, their institutions, and professionals - possessed no autonomous, essential values whose realization, in turn, the State had to secure and respect. Suddenly, this argument became suspicious of covering up for public servants maintaining professional privileges or spurious interests that could not be openly confessed (Siltala 2013). Through privatization, neoliberalism imposed the idea that there was no justification outside the market; rather, it was the market that should establish what health care, education, or social welfare (or transportation, or postal communication, or airport security, as a matter of fact) were, in the same way as it established the price and value of commodities: through the well-known mechanisms of supply and demand (Dardot \& Laval 2010/2014). In the end, the basic assumption of neoliberalism was that the meaning of the different social spheres was not for the State and specific, autonomous professionals to secure and determine. As Lorenz (2012) reminds us, "neoliberalism silently uncouples the globalized individual from the fundamental rights formerly connected to national citizenship" (p. 602). Health care, for example, would simply be what independent, rational customers wished to buy into as health care.

From the 1980s onwards, on the tracks of the oil crisis, neoliberalism found an indirect way to impose itself, one different from privatization: New Public Management (NPM from now on). The literature defines this model as the "application of [the] dogmas of the neoliberal economy to the domain of what used to be called the public sector" (Lorenz 2012, p. 603). “A key aspect of NPM," Vivian and Maroun (2018) underline, “is the view that the public sector should replicate policies and practices that are already accepted or institutionalized in the private sector" (p. 47). As can be seen, NPM- the administrative model that came to replace PPA by the 1990s - presented itself as a 
surprising mix: Unlike privatization, it kept alive capitalism's traditional enemy-the public sector-but under a completely different guise (Ellwood \& Newberry 2007). It was more interested in managing the state as if it were a company than in directly privatizing it (Botticelli 2017) (although this could easily be the end-result of NPM logic). In the final chapter of The road from Mont Pèlerin, Mirowski (2009) agreeably concluded that "a primary ambition of the neoliberal project is to redefine the shape and functions of the state, not to destroy it" ( $p, 436)$. Indeed, the main characteristic of NPM was that it substituted market-based principles for the plural rationalities that, as explained previously, the State was traditionally willing to respect and protect. Through a bizarre isomorphic process, the State mirrored the market and ended up hollowing out the specific meanings of the different social practices, assuming that the fundamental services that the public sector provided could be managed according to the transparent, universal, and authoritarian logic of "cost efficiency" and "value for money" (Adi \& Dutil 2018). Supply and demand should substitute for all the social rationalities.

As LeGrand (1999) analyzed in depth, this logic became embodied in a massive cohort of managers_-even meta-managers_-placed at the head of public sector departments. Unsurprisingly, their arrival brought forth a radical transformation of civil servant typology, especially in relation to the blend of theory and practice that had traditionally characterized its professional ethics and vocation (Talshior 2015) and which had been closer to Dewey's vision of democracy. As opposed to regular civil servants working in public sector departments, managers tended to have an economic background and little to no experience or familiarity with the professionalism of the spheres that they came to supervise. On many occasions, this discrepancy led to intra-departmental conflicts with workers whose expertise and autonomy were suddenly rendered redundant by 
newcomers who, despite their field-specific ignorance, had the authority and the winning hand in the decision making process. In what was a radical turn in the theoretical/practical divide at the public sector, managers presented themselves as neutral supervisors, experts who "claim[ed] to possess universally valid knowledge about organizational cooperation" (Siltala 2013, p. 472).

As was soon to be discovered, the managers' function was to establish a growing accountability system upon which to base and justify cost-reduction strategies. This played an important part in the expansion of neoliberal audit culture (Power 1997). As opposed to PPA's noninvolvement in the quality of the work performed-according to Vivian and Moron (2018), PPA accountability focused only on the financial dimension-NPM included qualitative, performance indicators. The problem lay in that these indicators assumed and unfolded the conceptual shift from effectiveness to economic efficiency (Stone 2002), thanks to which the indivisible nature of field-specific social actions was broken down into quantifiable factors (Hood 1991) whose main merit lay, in turn, in that they could be easily translated into specific budget lines. This understanding of social actions was completely foreign to Dewey's own and to his conception of a purposeful act, which was not a sum of elements but rather the complete deployment, in space and time, of an intentional arch that started in imagination and ended up transforming reality (Dewey 1916/2012). By contrast, to the extent that NPM retranslated a social practice as complex as "education", for example - linked to values and philosophical conceptions of society, as we saw above - into quantifiable test scores (Au 2011) or higher-education rankings, highschool and university managers could conjure a simplified image of their social practice to single out certain essential aspects over other, less important ones (Hursch 2007; Shore 2010). 
In the end, NPM's increasing focus on efficiency and economy was not necessarily compatible with the satisfaction of the specific values and aims of the social practices to which it was applied. The reverse was typically the case. For example, once nursingwhose aim Stradas, Wackerhausen, and Bondas (2018) define as providing "quality of life as experienced by the patient" (p. 6) —was reduced to a set of predefined tasks that had to be forcefully completed in a certain number of minutes/hours per week, the context was set for uncaring relationships to come in the way of professional practice. Similarly, "the economic NPM definition of education ignores the most important aspects of the education process and therefore poses a fundamental threat to education itself", reminds Lorenz (2012, p. 600). These two examples show that NPA's restructuring processes started to challenge the delicate ecology that made education or health care possible in the public sector; finally, this ecology was given up on. Continuous budget cuts, staff reduction, service fragmentation, externalization, and privatization render it impossible for professionals working in each of these professional spheres to carry out their work properly, according with their internal quality standards. This process of corruption is simply a consequence of the State not protecting and assuming the qualitative logics of the social spheres that NPM aimed to supervise, let alone giving them priority over costefficiency demands. "For this reason," Lorenz (2012) adds, "the introduction of the management model itself is a process of de-professionalization" (p. 613). Indeed, once management sacrifices the core values of a given professional sphere, cost-efficiency remains the only guiding principle. Without an additional qualitative ratio, every additional cut in spending can be justified in its name.

The previous section described Dewey's democratic ideal in terms of individuals who freely and equally participated in the theoretical and material production of their own 
society, not just in designing its aims but also in bringing them into practice. Dewey specially wanted this ideal to make its way to industry, which had to open itself to democratic and scientific inquiry. Now, however, we must conclude that neoliberalism's success through privatization and NPM strengthened the theory and practice divide and damaged the quality of democracy. It did so by imposing (1) a drastic reduction and impoverishment of the theory upon which social practices (and social life in general) used to be built, in a process that Broudy (1981) aptly defined as de-valuation; and (2) by enforcing an even more intense expropriation of theory in the hands of an elite of managerial caste that has remodeled and reinforced the theory vs. practice divide in the workplace. As a result, not only have neoliberal market principles become the only valid rationality for human interaction — not only have they come to replace a diversity of aims, values, and social meanings - but their design and conception have been thrust onto the hands of a hierarchy of experts-managers who display a single-minded, economic bent. Meanwhile, the majority of workers have been turned into clerks bereft of their right to exercise their vocation and professional autonomy (Talshior 2015). Bearing all this in mind, it should come as no surprise that the public sector has already been compared with the situation of industrial workers in Dewey's day: "Standardization, division of work, the separation of monitoring from making, de-skilling have triumphed in the fields formerly ruled by middle-class professional cultures at the universities, in hospitals, and in schools" (Siltala 2013, p. 471). Indeed, it is the nightmarish reversal of Dewey's democratic promise.

\section{Action research and democracy}

In this section the article explores the extent to which action research can genuinely become a powerful means to actualize Dewey's democratic ideal in the midst of 
contemporary privatization and NPM. Action research should guide the institutional reform which aims to strengthen and improve democratic life in our society, a reform that is barely tackled or introduced in Dewey's work (on account of his superficial treatment of the institutional dimension of democracy) and which is even more necessary today, in the midst of neoliberalism, than it was in Dewey's lifetime. That Dewey's philosophy and action research share affinities is beyond dispute (Boog 2003; Harkavy \& Puckett 2014; Stark 2014), since his work is one of the inspirations - together with Lewin's (1946) social psychology, with which it shares no small number of traits (Allport 1948)—consistently mentioned in action research literature. In line with this view, this section defines action research precisely by focusing on its effort to keep science and practice together (Adelman 1993). This has previously occurred in Dewey's pragmatist epistemology (Biesta 2014), which articulated science and practice in a similar way to how education and society were organized in Democracy and education. Thus, just as education should not forgo the basic elements of social interaction — deliberation, a social purpose, and a practical dimension — if it was to avoid turning itself into a meaningless and repetitive activity, scientific inquiry needed both to arise and return to the contexts, practices, and situations of the daily life (Argyris, Putnam, \& McLain Smith 1985). Otherwise, it would separate itself both from the paths of individual growth and social improvement (Dewey, 1916/2012); it would become "bookish" and assimilate itself to "pure theory", to what the ancient Greeks called theoria (Carr 2006).

Action research fully assumes this perspective, while also making it more concrete than it appears to be in Dewey's pragmatism. As a result, I believe it also pushes pragmatism to its full epistemological, social, and ethical consequences (Stark 2014). A general transition can be noted from practice understood as an epistemological category, 
i.e., an abstract dimension of human inquiry (which Dewey connected to certain professions or institutions), to action research's focus on fully contextualized social practices. Like pragmatism, action research is not interested in the positivist conception of knowledge but only in producing the "knowledge that counts", that is, only the knowledge necessary for "the improvement of practice" (Brydon-Miller, Greenwood, \& Maguire 2003, p. 13).

Let me delve into this matter a bit more, since this is where action research finds its specific worth. Allow us to say that society is made up of different social spheres, each of which involves different practices - education, health care, social welfare, and so on. Some of these practices develop within institutions - like schools and hospitals — and others not, but all of them have their own specific meanings, aims, values, and principles of procedure; what Kemmins (2008, p. 4) called the "traditions in a field" (now strongly challenged by NPM), against which the quality of each specific social action was traditionally verified and assessed. If all this is true, then action research can be understood as a form of scientific inquiry oriented towards improving each of these social practices in the original contexts where they take place, and in accordance with their traditional norms and values. "The fundamental aim of action research", said Elliott (1991), "is to improve practice rather than to produce knowledge. The production and utilization of knowledge is subordinated to, and conditioned by, this fundamental aim" (p. 4).

It is important for us to understand that the principled rationalities of each social practice function as the alpha and the omega of action research, which limit as much as qualify the many dimensions of the inquiry. This is so because the improvement of practice implies a series of epistemological, ethical, and methodological conditions that action research identifies and seeks to satisfy. One of them is that research needs to be conducted 
by the same people engaged in the social practice whose betterment is being pursued (McIntyre 2007). Action research clearly denounces that the theory vs. practice divide imposed by contemporary (neoliberal) social division of labor and education is incompatible with professional education and growth, even though the latter divide seems to be perfectly tuned to the epistemology and advancement of positivist science that takes place in neoliberal academic institutions (Brydon-Miller, Greenwood, \& Maguire 2003, pp. 22-23). Naturally, not only are the professionals of a given social practice best familiarized with the values and aims at stake —-they are the "custodians of the practice for their times and generation", as Kemmis (2010, p. 420) said—but the truth is that only they can fully access the contexts where these actions are led (Stenhouse 1979/2012). This aspect is very significant, since improvement of practice through action research (what Dewey would call "education" and "growth") can only occur amid the "multidimensional, dynamic, and complex" (Greenwood 2018, p. 77) contexts where the social practices tend to unfold; i.e., in natural situations, in contrast with laboratories that falsify and nullify the internal and conflictive nature of social actions. In a similar manner, for Dewey (1915/2001) education would remain utterly impossible in schools that had "lost their social spirit" (p. 11), that had disconnected from the structural elements of constituted social life.

Brief as this synthesis has been, I hope it has justified the claim that action research shares basic tenets with Dewey's idea of democracy and education, and that—precisely due to this - it can fight against some of the dynamics triggered by neoliberalism. Action research may be extremely well suited to reverse de-valuation and expropriation of theory that NPM and privatization have enforced since it considers the internal rationalities of professional practice to be "valid and vital" knowledge (Brydon-Miller, Greenwood, \& Maguire 2003, p. 11), theories built "for particular substantive and institutional purposes" 
(McTaggart 1994, p. 332). These rationalities must not be lost and forgone, and especially not sacrificed to market fundamentalism; in fact the opposite is true. They should be built on, improved, and refined through the ecological and deontologically-oriented forms of inquiry that action research affords.

From a certain angle, it seems as though action research recouples the theoretical and practical dimensions of each social practice by embracing research as a path for professionals to channel, express, and reinforce their vocation. This professional definition notwithstanding, the justification for action research would not lie as much in the institutional effectivity it may trigger as in its unwavering faith, shared with Dewey (1939/1982), "in the possibilities of human nature" (p. 229), in the entire scope and wealth of its skills. Action research also believes that life, work, and education should be intrinsically rewarding. While Lewin's early initiatives demonstrated through quantitative studies that democratization in the workplace can lead to increased productivity (Adelman 1993), the ultimate goals of action research would be more far-reaching and should not to be coopted by ideologies of "quality control" and "staff development" (Cooke 2006). The emancipatory potential of action research may include individuals having "a sense of control of their own work" (McTaggart 1994, p. 321), but its ultimate goals overlap with Dewey's utopian thoughts about democracy. Whatever the many personal and institutional gains derived from action research may be, they should be understood as a further step in the "ongoing process of citizens working toward cooperative, shared governance of social institutions, including those of the market", which was how Box, Marshall, Reed, and Reed (2001) described Dewey's general project. Action research would also belong in a bigger picture in which professionals would gradually take control of all the dimensions in their life, precisely by insisting on, and at the same time letting themselves be carried away by, 
action research's expanding democratic spiral. As a result, Dewey's utopia might well be reformulated in terms of life (and work) consisting of a never-ending series of action research projects.

\section{Institutional implications}

How can action research actually contribute to transforming the neoliberal landscape? In this final section I would like to focus on action research's potential to gear institutions towards Dewey's democratic goals. In their criticism of Dewey's work, Straume (2016) and Bernstein (2010) alluded to the fact that Dewey did not elaborate on the institutional framework that could advance his ambitious aims for democracy. However, rather than new institutions, it might be the case that Dewey's utopia demanded new ways of breathing democratic life into the existing ones. Following through the different methodological phases of action research projects (Burns 2005), we can imagine how their deliberative phases might give professionals the chance to reformulate the abstract aims, values, and principles of procedure of their own social spheres to adapt them to the changing circumstances of their social environment. Next, the flexible participatory methods of action research would allow workers to use their strategic thought to imagine and design more adequate means to realize the aims and values of their practice. And ultimately, across different cycles of inquiry, workers would be able to obtain, share, and triangulate the evidences needed to assess the success of their initiatives, and use them to prepare ensuing projects that either build on or reformulate their goals.

Still, doubts remain as to the possibility of action research ever fulfilling Dewey's promise. Since Dewey first wrote Democracy and education, the obstacles that came in the way of his original project have become more difficult to overcome. At present, global and local socio-economic conditions impose severe restrictions on the space actually allowed 
for professionals to explore and enrich the democratic substratum of their institutional contexts. The chances are that NPM will not tolerate democratic reconstructions of the workplace even when they focus on strictly professional aspects, and that it will even crush and arrest them the moment they begin to question — as they should eventually do (McTaggart 1994) - power relations in society: for instance, how they impinge on a given social practice, and the responsibility that the corresponding professionals may have for maintaining the status quo. Nonetheless, action research is in a good position to justify itself even against these claims. For, rather than accepting and taking for granted the devaluation and expropriation of theory and the deskilling that go with neoliberal dynamics, action researchers can argue that it is precisely by strengthening the autonomy of their respective practices that they resist the economic colonization of the entire social landscape. In other words, by holding on to their specific ratios workers may not only come to enjoy the internal goods of their professions (MacIntyre 1981/2011) but also make sure that human and economic resources are allocated, distributed, and deployed according to a wider diversity of aims, needs, and perspectives than those mobilized and spent in the interest of capital accumulation. It is by building on their vocations that action researchers make sure that wealth is actually redistributed, and does not simply return to the hands of the powerful. Even if only as a bulwark against market totalitarianism, action research remains a logical and valuable tool for the benefit of democracy.

In line with this argument, action research may even bear within itself a democratic alternative to the two models of public management and administration that have shaped the last fifty years of Western institutional life: NPM and the model it originally came to replace, PPA. PPA helped to unfold a social-democratic understanding of the public sector, while NPM ensued from and performed a neoliberal one. PPA was financially- and 
process-oriented, meaning that its own mechanisms of accountability focused on verifying the allocation and deployment of economic resources without explicitly assessing the quality of the given service. Vivian and Maroun (2018) thus highlighted the "independence of the public servant from the political process" as one of PPA's main traits: "Elected officials make decisions on what needs to be done while public servants implement policy decisions” (p. 46). This separation catered for autonomy and professional vocation. By contrast, with NPM accountability was goal oriented, and interested in examining the endresults of the service afforded. Yet the problem with NPM assessment was not that it was qualitative but, rather, that it was neoliberal, meaning that the criteria and standards it employed did not respect the specific rationalities of the different social practices represented in the public sector. Instead, NPM broke down the internal, indivisible quality of educational, health-related or welfare actions to bend them and make them conform to value-for-money rationality.

Bearing all this in mind, contemporary public management and administration appears to be trapped and paralyzed by the following situation: On one hand, PPA enforced a quantitative focus designed to secure the autonomy of each social practice, but not its quality. On the other, NPM enforces a qualitative focus that cannot improve service quality, simply because it destroys its autonomy. Action research may help find a way out of this conundrum precisely due to its radical democratic potential. Its main contribution to institutional administration may consist, firstly, in its clear understanding (afforded, among others, by Dewey's ideas on democracy) that the quality of the actions involved in each social practice can and should be assessed and accounted for, but only in accordance with the aims, values, and principles that are internal to it, and all of which have a raison d'être. And second: to the extent that professionals are not only practitioners but are in fact those 
best acquainted with field-internal theories, action research recommends that they fully engage and participate in the accountability process, which could easily be conducted as part of the assessment stage of action research projects. By formulating their own aims, their own strategies, methods of research, and assessment criteria, civil servants would realize, no matter how humbly, Dewey's democratic goals. They would freely and equally participate in the theoretical and material production of their social practice, their institutions, and their society, by designing its aims but also by bringing them into practice. So as long as there remains the wish to link individual, professional growth to a more adequate transformation of society, action research will remain a meaningful resource.

\section{References}

Adelman, Clem. 1993. Kurt Lewin and the origins of action research. Educational Action Research, 1(1), 7-24.

Adi, Sana, and Dutil, Patrice. 2018. Searching for strategy: value for money (VFM) audit choice in the new public management era. Canadian Public Administratio, 61(1), 91-108.

Allport, Gordon W. 1948. Foreword. In Kurt Lewin and Gertrud Weiss Lewin (ed.), Resolving social conflicts: selected papers on group dynamics (pp. vii-xiv). New York, NY: Harper \& Row.

Argyris, Chris., Putnam, Robert, and Smith, Diana McLain. 1985. Action science. San Francisco: Jossey-Bass.

Au, Wayne. 2011. Teaching under the new Taylorism: High-stakes testing and the standardization of the 21 st century curriculum. Journal of Curriculum Studies, $43(1), 25-45$. 
Bauman, Zygmunt. 1987/2013. Legislators and interpreters: On modernity, post-modernity and intellectuals. Cambridge: John Wiley \& Sons.

Bernstein, Richard J. 2010. Dewey's vision of radical democracy. In M. Cochram (ed.), The Cambridge Companion to Dewey (pp. 288-308). Cambridge: Cambridge University Press.

Biesta, Gert. 2014. Pragmatising the curriculum: Bringing knowledge back into the curriculum conversation, but via pragmatism. Curriculum Journal, 25(1), 29-49.

Boog, Ben W. 2003. The emancipatory character of action research, its history and the present state of the art. Journal of Community \& Applied Social Psychology, 13, 426-438.

Boostrom, Robert. 2016. The peculiar status of Democracy and Education. Journal of Curriculum Studies, 48(1), 4-22.

Botticelli, Sebastián. 2017. La impronta neoliberal en el New Public Management: governar a través del mercado [The neoliberal mark in New Public Management: governing through the market]. Trabajo y sociedad, 29, 677-693.

Box, Richard C., Marshall, Gary S., and Reed, B.J., and Reed, Christine. 2001. New public management and substantive democracy. Public Administration Review, 61(5), 608619.

Boyles, Deron. 2000. American education and corporations: The free market goes to school. New York: Routledge.

Broudy, Harry S. 1981. Truth and credibility. New York: Longman.

Brydon-Miller, Mary, Greenwood, Davydd., and Maguire, Patricia. 2003. Why action research? Action Research, 1(1), 9-28. 
Burns, Anne. 2005. Action research: An evolving paradigm? Language teaching, 38(2), 5774.

Carr, Wilfred. 2006. Philosophy, methodology and action research. Journal of Philosophy of Education, 40(4), 421-435.

Cooke, Bill. 2006. The Cold War origin of action research as managerialist cooptation. Human Relations, 59(5), 665-693.

Cunha, Marcus Vinicius da. 2016. We, John Dewey's audience of today. Journal of Curriculum Studies, 48(1), 23-55.

Dardot, Pierre, and Laval, Christian. 2010/2014. The new way of the world. On neoliberal society. London: Verso.

Detlefsen, Karen. 1998. Diversity and the individual in Dewey's philosophy of democratic education. Educational Theory, 48(3), 309-329.

Dewey, John. 1897/1998. My pedagogic creed. In Larry Hickman, and Thomas M.

Alexander (eds.), The essential Dewey. Volume 1. Pragmatism, education, Democracy (pp. 229-235). Bloomington \& Indianapolis: Bloomington.

Dewey, John. 1915/2001. The school and society. In J. Dewey, The school and society \& The child and the curriculum (pp. 1-102). Mineola, NY: Dover Publications.

Dewey, John. 1916/1980. The need of an industrial education in an industrial society. In Jo Ann Boydston (ed.), John Dewey: The middle works, vol. 10 (pp. 137-143). Carbondale: Southern Illinois University Press.

Dewey, John. 1916/2012. Democracy and education. An introduction to the philosophy of education. New York: Macmillan \& Forgotten Books.

Dewey, John. 1927/1998. Search for the great community. From The Public and Its Problems. In Larry Hickman, and Thomas M. Alexander (eds.), The essential 
Dewey. Volume 1. Pragmatism, Education, Democracy (pp. 293-307).

Bloomington, IN: Indiana University Press.

Dewey, John. 1931. Individualism: old and new. London: George Allen \& Unwin LTD.

Dewey, John. 1939/1982. Creative democracy—the task before us. In J. Boydston, John

Dewey. The later works (Vol. 14, pp. 229-230). Carbondale: Southern Illinois Press.

Dewey, John. 1941/1988. The basic values and loyalties of democracy. In Jo Ann Boydston

(ed.), John Dewey: Later works, vol. 14 (pp. 275-277). Carbondale: Southern

Illinois University Press.

Elliott, John. 1991. Action research for educational change. Milton Keynes: Open University Press.

Ellwood, Sheila, and Newberry, Susan. (2007). Public sector accrual accounting: institutionalising neo-liberal principles? Accounting, Auditing \& Accountability Journal, 20(4), 549-573.

Gonon, Philipp. 2000. Education, not democracy? The apolitical Dewey. Studies in Philosophy and Education, 19, 141-157.

Greenwood, Davydd J. 2018. Action research. In Malgorzata Ciesielska and Dariusz Jemielniak (eds.), Qualitative methodologies in organization studies. Volume I: Theories and New Approaches (pp. 75-98). New York: Palgrave Macmillan.

Harkavy, Ira and Puckett John L. 2014. John Dewey. In David Coghlan and Mary BrydonMiller (eds.), The SAGE encyclopedia of action research (Vol. 1, pp. 252-256). London: SAGE.

Harvey, David. 2005. A brief history of neoliberalism. Oxford: Oxford University Press. Hood, Christopher. 1991. A public management for all seasons? Public Administration, 69(1), 3-19. 
Hursch, David. 2007. Assessing No Child Left Behind and the rise of Neoliberal education policies. American Educational Research Journal, 44(3), 493-518.

Judt, Tony. 2011. Ill fares de land. A treatise on our present discontents. London: Penguin.

Kemmis, Stephen. 2010. What is to be done? The place of action research. Educational Action Research, 18(4), 417-427.

Kemmis, Stephen and Smith, Tracey. 2008. Praxis and praxis development. In S. Kemmis, \& T. Smith (eds.), Enaling praxis: challenges for education (pp. 3-13). Rotterdam: Sense.

Kerschensteiner, Georg. 1933. Theorie der Bildungsorganisation (Vol. I). Leipzig: Teubner.

Kilpatrick, William Heard. 1918. The project method. The Use of the Purposeful Act. New York: Teachers College, Columbia University.

Kliebard, Herbert M. 2006. Dewey's reconstruction of the curriculum: from occupations to disciplined knowledge. In David T. Hansen, John Dewey and our educational prospect (pp. 113-128). Albany, NY: State University of New York Press.

Knight Abowitz, Kathleen. 2008. On the public and civic purposes of education. Educational Theory, 58(3), 357-376.

LeGrand, Julian. 1999. Competition, cooperation, or control? Tales from the British national health service. Health Affairs, 18, 27-39.

Lewin, Kurt. 1946. Action research and minority problems. Journal of Social Issues, 2(4), $34-46$.

Lorenz, Chris. 2012. If you're so smart, why are you under surveillance? Universities, neoliberalism, and new public management. Critical Inquiry, 38(3), 599-629. 
Luke, Allan. 2018. Preface. In A. Luke, Critical literacy, schooling, and social justice. The selected works of Allan Luke (pp. vii-xvi). New York: Routledge.

Lynn Jr, Laurence E. 2006. Public management: Old and new. New York: Routledge.

MacIntyre, Alasdair. 1981/2011. After virtue. A study in moral theory. London:

Bloomsbury.

Mansfield, Becky. 2007. Privatization: property and the remaking of nature-society

relations: introduction to the special issue. Antipode, 39(3), 393-405.

McIntyre, Alice. 2007. Participatory action research. Thousand Oaks: Sage.

McTaggart, Robin. 1994. Participatory action research: issues in theory and practice. Educational Action Research, 2(3), 313-337.

Mirowsky, Phillip. 2009. Postface: Defining Neoliberalism. In P. Mirowsky and Dieter Plehwe (eds.), The road from Mont Pèlerin. The making of the neoliberal thought collective (pp. 417-456). Cambridge, Mass.: Harvard University Press.

Morales, Jérémy, Gendron, Yves, and Guénin-Paracini, Henri. 2014. State privatization and the unrelenting expansion of neoliberalism: the case of the Greek financial system. Critical Perspectives on Accounting, 25, 423-445.

Noddings, Nel. 2010. Dewey's philosophy of education: a critique from the perspective of care theory. In M. Cochran (ed.), The Cambridge companion to Dewey (pp. 265287). Cambridge: Cambridge University Press.

Power, Michael. 1997. The audit society: rituals of verification. Oxford, UK: Oxford University Press.

Saltman, Kenneth J. 2012/2015. Failure of corporate school reform. New York: Routledge. Shore, Cris. 2010. Beyond the multiversity: neoliberalism and the rise of the schizophrenic university. Social Anthropology, 18(1), 15-29. 
Siltala, Juha. 2013. New Public Management: the evidence-based worst practice? Administration \& Society, 45(4), 468-493.

Stark, Jody L. 2014. The potential of Deweyan-inspired action research. Education and Culture, 30(2), 87-101.

Stenhouse, Lawrence. 1979/2012. Research as a basis for teaching. In J. Elliott, \& N. Norris (eds.), Curriculum, pedagogy and educational research (pp. 122-136). New York: Routledge.

Stone, Deborah. 2002. Policy paradox: the art of political decision making. New York, NY: Norton.

Stone, Lynda. 2008. Speculation on a missing link: Dewey’s democracy and schools. Journal of Educational Controversy, 3(3), 1-14.

Stone, Lynda. 2016. Re-thinking Dewey's democracy: shifting from a process of participation to an institution of association. Journal of Curriculum Studies, 48(1), $77-93$

Stradas, Maria, Wackerhausen, Steen and Bondas, Terese. 2018. The nurse patient relationship in the New Public Management era, in public home care: a focused ethnography. Journal of Advanced Nursing. https://doi.org/10.1111/jan.13850

Straume, Ingerid S. 2016. Democracy, education and the need for politics. Studies in Philosophy and Education, 35, 29-45.

Talshior, Gayil. 2015. Models of public servants' training and the crisis of democracy: from 'Politics as vocation' to the 'effective bureaucrat'. In F. Sager, \& P. Overeem (eds.), The European public servant. A shared administrative identity? (pp. 273-294). Harbour House, UK: ECPR Press. 
Vivian, Bruce and Maroun, Warren. 2018. Progressive public administration and new public management in public sector accountancy: an international review. Meditari Accountancy Research, 26(1), 44-69.

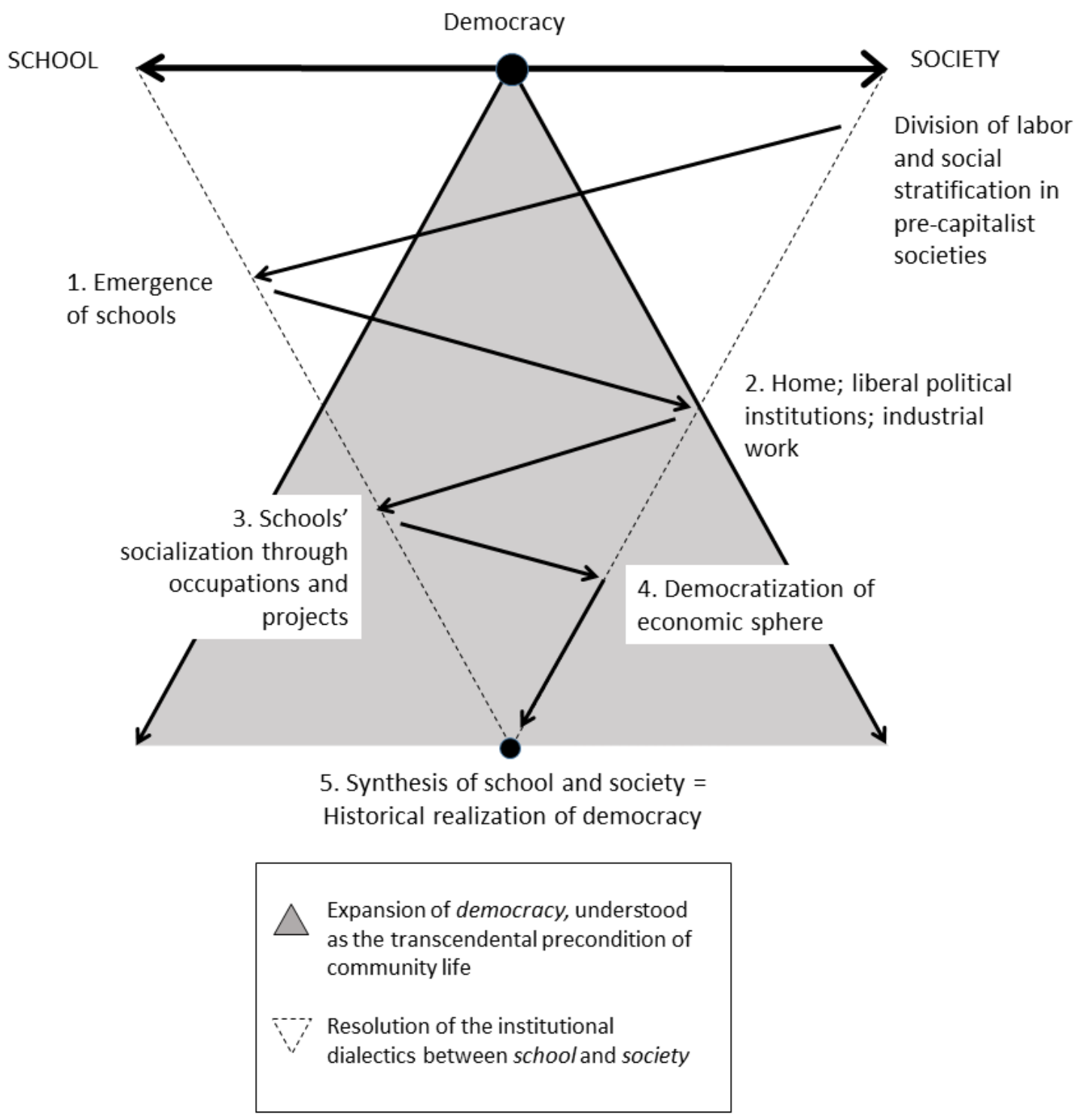

\section{Figure 1.}

